\title{
The Uses of Denominational History
}

\section{A Conversation with Margaret Bendroth, Thomas Kidd, Keith Harper, and Robert W. Prichard}

\section{Conducted by Lincoln A. Mullen}

Margaret Bendroth, Congregational Library and Archives

Thomas Kidd, Baylor University

Keith Harper, Southeastern Baptist Theological Seminary

Lincoln A. Mullen, George Mason University

Robert W. Prichard, Virginia Theological Seminary

Mullen: American religious history has a standard narrative of how the field developed. The field used to be dominated by denominational histories, more often than not written by scholars from those denominations. Some of these massive works of scholarship, such as those written by William Warren Sweet, made a genuine contribution to the field, but most bordered on antiquarianism. The field eventually set aside denominational history for several reasons. Most important, historians of religion moved on to other concerns besides theology and institutional history, turning their attention to the discussions of race, class, gender, and power that animate the historical professions more generally. Historians aimed to leave behind the mainstream and the mainline in favor of history written from the margins. Religious history distanced itself from church history, a field which was supposedly constrained by denominational history. Even within church history, H. Richard Niebuhr had provoked (as Keith Harper has pointed out) a suspicion that denominations were undesirable features of American Christianity and so unworthy of scholarly attention. Then too, as Robert Wuthnow described in The Restructuring of American Religion, the role of denominations and denominationalism diminished after World War II, and their decline in American religious life was matched by a declining interest among historians of American religion.

At least, that is how the story goes. Even as denominational history moved to the sidelines, scholars of religion still have had to take denominations into account. Successful histories written from the margin, or concerned with race or gender, have succeeded at those aims precisely because they wrote from the perspective of some non-mainstream denomination. Religious historians still tend to write their books religious group by religious group, even if they do not label their work as denominational history. And very recently historians have been writing 
denominational histories concerned with questions of race and memory. What then is the place of denominational histories in American religious history?

At the October 2016 meeting of the Conference on Faith and History, four scholars who have written denominational histories (among their many other books) gathered for a roundtable discussion of "The Uses of Denominational History." Margaret Bendroth, Executive Director of the Congregational Library in Boston and recent president of the American Society of Church History, is the author of a pair of books on denominations: The Spiritual Practice of Remembering (Eerdmans, 2013) and The Last Puritans: Mainline Protestants and the Power of the Past (University of North Carolina Press, 2015). Thomas Kidd, Distinguished Professor of History at Baylor University, is the co-author with Barry Hankins of Baptists in America: A History (Oxford University Press, 2015). Keith Harper, Senior Professor of Baptist Studies at Southeastern Baptist Theological Seminary, is the author or editor of several books on Baptist history, including The Quality of Mercy: Southern Baptists and Social Christianity, 1890-1920 (University of Alabama Press, 1996) and American Denominational History: Perspectives on the Past, Prospects for the Future (University of Alabama Press, 2008). Robert W. Prichard is the Arthur Lee Kinsolving Professor of Christianity in America and Instructor in Liturgy at Virginia Theological Seminary and author of A History of the Episcopal Church, 3rd rev. ed. (Morehouse, 2014).

At the panel these historians reflected on how they structured their denominational histories and who their audiences were, on what it might mean for denominational histories to be written from an insider's perspective, and on how their books fit into the field of American religious history more broadly. The following is an elaboration of the responses they gave at that roundtable.

\section{Mullen: What were you trying to accomplish in writing your denominational histories?}

Bendroth: I was trying to accomplish more than one thing, for sure. To begin with, I had some practical concerns, growing out of my job as executive director at the Congregational Library \& Archives. I work every day in the middle of a fabulous archival collection that just doesn't get enough use. Since I arrived there in 2004 I have tried every way I could to pique scholarly curiosity, especially about the wealth of virtually untouched 19th and 20th century denominational material in our rare book room. So I took on the project of writing the history of Congregationalists-post-Puritans and post-Jonathan Edwards_for the sake of the collection.

That took care of another problem too. My job allows limited time and money for off-site research-I am there to make sure the bills get paid and the trains move on time. It's difficult if not impossible to carve out hours at a time for research-something always comes up. My revenge was sneaking off to the rare book room every chance I got, trips that in the end made the administrative work more bearable. 
I also had a scholarly agenda. My larger concern was addressing some unexamined assumptions about mainline Protestants, especially the idea that they are basically "failed evangelicals." Since the 1980s historians have done a pretty good job explaining fundamentalists and evangelicals - to the point that they've come to define our narrative of religion in the twentieth century, a tale of conflict, division, and resurrection, all against a backdrop of mainline fecklessness and evangelical energy. The time I spent poking around the archive, reading material left behind by laypeople, convinced me that there is something more to Protestant liberalism, something historians have not yet really named. The famous doubters, skeptics, and compromisers do not represent the whole, nor do the feckless bureaucrats. Within local churches I saw spiritual yearning and warm piety, increasingly tinged with a sense of irony about it all, a wry smile behind the traditional forms of religion.

Prichard: I have written three different editions of a denominational history. The first edition of $A$ History of the Episcopal Church appeared in 1991, the second in 1999, and the third in 2015.

In the preface to the first edition I listed five reasons for which I wrote. I offered a more modest two reasons in the introduction to the second edition, but went back to five reasons in the third edition. They all boil down to this: I wanted a usable and up-to-date text for a class that I have been teaching in history of the Episcopal Church since 1980 and there was no work in print that was adequate. The history previous to mine (Raymond Albright's History of the Protestant Episcopal Church) had appeared in print in 1964, but with the exception of a few well-placed paragraphs in the last chapter, its narrative ended in about 1955. Bringing the story up to date involved expanding coverage on the role of women in the church. (In the 1980s a colleague of mine pointed out that the only name of a woman in the index for Albright's volume was the Virgin Mary.) It involved adding to the story of the Civil Rights and ecumenical movements, addressing the numerical decline in the mainline churches that began with the end of the baby boom in 1965, acknowledging the American divisions in church and society over the War in Vietnam, and telling the story of liturgical reform. There was much that needed to be included to make the narrative current.

I did, of course, have some ideas about what I understood to be a useable narrative. For me that meant a narrative that took notice of contemporary scholarship and paid attention to developments in other denominations and in the society at large. I tried to avoid the nearsightedness that leads some denominational historians to write as if the church they chronicle existed in a vacuum and there were no other people of faith in the land. As a result I shaped my narrative in some ways that were significantly different from my predecessors. I wrote about Anglican supporters of the Great Awakening, included a section on Methodist reorganization after the American Revolution alongside discussion of competing Middle colony and Connecticut efforts in what would become the Episcopal Church, discussed the relationship between early Episcopal and African Methodist Episcopal efforts at organization of congregations for African Americans in Philadelphia, traced the polemical exchanges between Roman Catholic Archbishop Francis Patrick Kenrick and Episcopal Presiding Bishop John Henry Hopkins, included a discussion of ways in which the Episcopal Church was affected by 
the modernist debate of the early 20th century, noted the divisive effect of the War in Vietnam, and observed that the Episcopal Church's statistical decline of the 1960s was shared by other mainline denominations.

Harper: Denominational histories have tended to emphasize a certain consensus in practice and theology for the sake of "telling the group's story." In my work I have tried to study other aspects of denominational life. This was especially true in The Quality of Mercy and Through a Glass Darkly. In the former I argued that turn-of-the-century Southern Baptists had a social conscience and acted on it. In the latter I sought scholars with appropriate expertise to write essays that explore "lesser known" aspects of the Baptist experience.

Kidd: Barry Hankins and I had been thinking of writing a denominational history of Baptists for years, simply because our respective specialties and interests synchronized so well for such a project. It was not hard to imagine a book in which I would work through Baptists in the first half of American history, and Hankins would handle the second half. We were surprised when our literary agent independently suggested that we do such a project. We would have assumed that denominational history would be seen as passé, but I believe that there is still a lively market for readable denominational histories, both among general readers affiliated with the denomination in question, and at denominational colleges and seminaries.

We were hoping that Baptists in America could offer a fresh narrative history of Baptists, especially by using Baptist history as a lens into broader American history. We sought to intertwine themes of interest to church historians, and themes of interest to American historians, even ones not especially concerned with religion.

\section{Mullen: Are denominational histories necessarily written from an insider's perspective? Put a different way, who was your audience for your books and how did you speak to people within the denominations that you wrote about?}

Bendroth: We always write with more than one audience in mind. One of the more important ones for me was the people l'd met over the years as I gave talks and lectures and sermons in Congregational churches across New England, and in the lands beyond. I suppose it's no surprise that the members of those churches know very little of their history. That's not necessarily their fault-factor in, for example, denominational mergers, the persistent localism of the Congregational tradition, and then a flood of ex-Catholics in recent years. But churches also don't provide any real opportunities for lay people to learn the history of their denomination, let alone their own congregation. It became clear to me that people did care about their history, and some even wanted me to "write something" that they said they would read. After I while I 
became convinced that if I did, some of them would actually do so. Surprisingly, that's proven to be true.

Of course all of this was trickier than it sounds. Writing denominational history requires a certain amount of guts and courage. My collection, for example, includes reams of material about the 1957 merger that created the United Church of Christ, a move fiercely opposed by many Congregationalists, who saw the move as the sad end of a grand tradition. Some of these erstwhile opponents are the Library's most faithful supporters. In other words, people I know (and who write checks to help me pay the bills here) had a stake in what I wrote about the merger. I don't think I necessarily pulled punches, but I definitely had to resist my native bent toward snarkiness, which was probably a good thing.

At the same time, however, the title of my book does not include the word "Congregationalist." My main goal was not to write a denominational history but a book about the power of history and memory. Congregationalists were a useful foil, a way of understanding how liberal mainline Protestants renegotiated historic obligations to their spiritual ancestors. Contrary to the stereotype, they were not adrift and traditionless-my Congregationalists thought about the past a lot, and argued incessantly about its implications for denominational polity-and they were far more historically rooted than their fundamentalist and evangelical cousins. (But that's another story.)

Kidd: We certainly imagined that our primary audience would be intellectually engaged Baptists, including pastors, academics, laypeople, and college students. Previous denominational histories of Baptists have tended to be more internally and institutionally focused than ours, however. Some offered histories of the growth of individual Baptist churches, denominations, and movements, giving details of the theological traditions associated with those movements and how those traditions have persisted (or not) through Baptist history.

Of course, some of those histories tended to be polemical, advocating for one tradition or another as the best and most representative of Baptists. More recent Baptist histories that dealt with the Southern Baptist tradition have often been formed by the authors' experiences during the Conservative Resurgence (or Fundamentalist Takeover, to detractors) that began in the SBC in the late 1970s.

Barry Hankins and I have our own theological views, of course, but we did not feel like we had an axe to grind with this book. We are both practicing Baptists, although we do not attend the same church in Waco. Neither of us were politically active in the denominational controversies related to the Conservative Resurgence. The fact that we are Baptists obviously was critical in inspiring us to write the book.

Moreover, we wanted readers to see how the Baptist tradition shaped, and was shaped by, broader themes in American history such as the rise of evangelical Christianity, the American Revolution, the Civil War, and the Civil Rights Movement. In that sense, we wanted to 
acknowledge Baptist distinctives but also to turn readers' view outward to see how the Baptist tradition interacted with larger American and Christian developments.

Prichard: The denominational historian is swimming in a smaller pond than is the person who is writing about the religious tradition of the United States or the Western World. In the case of a small denomination like the Episcopal Church, it means that one often has the chance to meet and know the people about whom one writes or their descendents. A historian of a small denomination may be more a more active participant in the story being told (or at least the final chapters of that story) than one who writes history on a larger scale. There are some obvious advantages to that role as participant. It provides for easier access to information. But there is the corresponding danger of losing perspective and reducing history to a catalogue of likes and dislikes.

When writing a denominational history, a reader's Christian faith can be assumed in a way that is not always the case when writing for a general public. One need not apologize or explain away the content of faith.

I had four audiences in mind when I wrote. I wrote for my colleagues at other institutions who taught the same subject and faced the same problem with out-of-date texts. Many of them read early drafts of chapters and made valuable comments on them. I wrote for those who I anticipated would be my students and for the members of the denomination at large. I was hopeful as well that what I had to say would be of interest to historians of other religious traditions and other parts of the world. One author who told me specifically that he had been influenced to write by seeing my effort was Alan L. Hayes of Wycliffe College of the University of Toronto, who went on to write Anglicans in Canada.

Harper: Denominational history tends to be written by "insiders" who are interested in aspects of their own religious experience, but this is not always the case. For instance, Christopher $\mathrm{H}$. Evans wrote a fine essay on the Baptist theologian and pastor Walter Rauschenbusch for Through a Glass Darkly. I wanted Evans to write the essay because he is the premier Rauschenbusch scholar in America. He is also a United Methodist. To your question about intended audience, apart from the Lottie Moon and Annie Armstrong correspondence, in which I had a distinctly Southern Baptist readership in mind, I try to speak to both "insiders" and "outsiders."

\section{Mullen: What is the place of denominational history in the field of religious history? How do your books connect to the rest of the field?}

Prichard: Denominational histories should both inform and be informed by those who are writing more general works on religious history, though that does not always happen.

Denominational historians have a responsibility to the broader academic guild. To put that in the 
negative, errors and questionable judgments can be picked up by others. Historian Martin Marty was inaccurate when he wrote in Pilgrims in their Own Land that Devereux Jarratt was the "one and only one Episcopal minister" to "take up revivalism in the style of Whitefield" (123), but he was hardly to blame; Episcopal historians to that point had done very little to let the broader story of Anglican involvement in the Awakening be known.

Denominational historians also have a responsibility to draw upon current scholarship and to make it available to their readers. Denominational histories should not be static; authors ought not simply add a recent chapter to what their predecessors have said-or what they themselves have said in earlier editions. The third edition of my History of the Episcopal Church is 130 pages longer than the second edition. Seventy of those pages represent rewriting of earlier chapters to take new scholarship into account. At least some readers have learned of works like William Pettigrew's Freedom's Debt, which offers a rethinking of the relationship between slavery and the Enlightenment, by reading the third edition.

Another way to say this is to say that denominational historians are middle persons. The general historians can't be counted on to know about a monograph on reorganization of an Episcopal parish in Berryville, Virginia in the early 20th century, but a denominational historian can often master that level of detail. The educated reader who has an interest in religion may not be aware of works like John Zaborney's Slaves for Hire, which explains how a rental system expanded the percentage of the nation that reaped the benefits of slavery, but may learn of such works by reading denominational histories.

The same standards of evidence and comprehensibility apply to denominational histories as to other works in the discipline. Denominational histories can be a point of entry into monographs on specific issues that might otherwise be overlooked. They also can point readers to synoptic studies about American and world religion. Well-written content footnotes about scholarship can be some of the best things about a denominational history.

Kidd: It would be hard to imagine getting away from denominational history in religious history. History thrives on controversy and change, and so much religious controversy and change has happened within the context of denominations. The fact that Barry and I are both trained as historians and housed in a history department at Baylor probably helps to explain why we would not be satisfied with a Baptist history that was just about the development of Baptist theology or Baptist institutions, however.

We assume that all people and denominations are inextricably shaped by the surrounding culture. Baptists exercised a profound influence on American ideals of religious liberty, for instance, but Baptists also found themselves shaped, wittingly or unwittingly, by concepts related to race and freedom that originated substantially from non-Baptist sources.

Harper: It depends on how one defines "denominational" history. Broad, over-arching works like H. Leon McBeth's The Baptist Heritage and more recently, Nathan Finn, Anthony Chute, and 
Michael Haykin's The Baptist Story and Tommy Kidd and Barry Hankins's Baptists in America are all very helpful in identifying key people, places, controversies, and the like. On the other hand, works that focus on specific aspects of groups like Southern Baptists can make significant contributions to U. S. religious history. Here, I am thinking specifically of Barry Hankins's Uneasy in Babylon: Southern Baptist Conservatives and American Culture and Elizabeth Flowers's Into the Pulpit: Southern Baptist Women and Power since World War II.

Bendroth: For me, denominational history is an access point into the concerns of laypeople. Congregationalists were a particularly apt group for this, as they have minimal hierarchy and considerable interplay between top and bottom and in between. A bureaucratic decision or a powerful sermon doesn't mean much if didn't resonate, if it didn't generate letters to the editor or new organizations in local churches. Denominational history is a relatively tidy way to see this interaction within a fixed setting over time.

Denominational history also gets us back into our sources. I came to realize during the course of my research just how much laypeople as well as clergy really cared about polity. They knew the differences between Presbyterian and Methodist organizational structures, the various titles employed-elder, deacon, bishop, ruling elder, priest-and of course they could tell you exactly where everyone else had gone off the rails. (Rancor against Catholics drew in part from this same energy, I think.) So, if we want to understand what people in the past cared about, thought about, how they came to various decisions, we need to be curious about polity. We should pay attention. It was a genuinely lively discourse!

\section{Mullen: What were the organizing principles of your histories? How did you bring questions of race, class, gender, power, and memory to bear on histories of denominations?}

Kidd: The three main themes of our book were Baptists and religious liberty, Baptists and race, and the idea of Baptists as both "insiders" and "outsiders" in American history. The essential contributions that Baptists made to the American tradition of religious liberty are well-known to specialists, but have become somewhat obscured in recent decades as more evangelicals, including some Baptists, have become wary of the "separation of church and state" as an idea embraced only by secularists.

Scholars like R. Laurence Moore and Christian Smith have explained how "outsiders," or at least religious groups who think of themselves as outsiders, have had such a large impact on American religion and American history. Baptists truly were outsiders for much of their history in America, as they were often banned, jailed, and persecuted by the established denominations up through the American Revolution. Even as white-led Baptist churches and denominations became more mainstream, black and other non-white Baptists still were marginalized within their own movement. Yet over the course of the nineteenth and twentieth centuries, black and white Baptists built some of the largest and most powerful religious organizations in America. 
But that outsider mentality, and a sense of battling existential threats for survival, remained a key part of Baptist identity.

Race plays both an ideological and an institutional role in our history. African American Baptists, and to a lesser numerical extent Native American, Hispanic, and Asian Baptists, found intellectual and spiritual resources within the Baptist tradition to help maintain dignity, hope, and community in the midst of a sometimes hostile dominant American society. White Baptists had a complex, troubled relationship with race. Fleeting egalitarianism in the eighteenth century was too often (though not always) replaced with racial paternalism in the antebellum era. Most famously, the Southern Baptist Convention was founded in 1845 in white southerners' effort to assert that slaveholders could remain in good standing with the churches and missionary agencies. Although the SBC apologized formally for its origins in 1995, questions of race and power remain live issues in the SBC through present day.

One way that we self-consciously tried to speak about ethnicity and Baptists was not to assume white Baptists as the "norm" and Baptists of color as the "other." We tried to be careful not to let just "Baptists" always mean "whites," with only "black Baptists" and other non-whites receiving the obligatory ethnic descriptor. Sometimes I tell my students to try thinking of African Americans as the normative evangelicals or Baptists, and whites as the exception-doing so helps to reveal how often we unconsciously do the opposite.

Prichard: It should be no surprise that contemporary historians pay more attention to race and gender than did their predecessors. I have included frank discussions about slavery (and the church's inadequate response to it), focused on the creation of African American parishes, paid attention of roles played by women (such as that of sexton) that have been previously overlooked, and have expanded coverage of the church's response to the post-1965 increase in immigration.

Bendroth: The organizing principle of my book was the construction of memory and identity, how Congregationalists rediscovered their ancestors and then deployed them in various ways. That meant that I started my research reading theory, trying to understand the dynamics of secularization and secularism, the role of memory in modern culture. When my brain felt reasonably full I started in on primary sources, but with an intellectual scaffold to build upon.

Race and gender are part of this story, for sure, but I came to realize that, in the case of Congregationalists, these were muted by its decentralized church structure and polity. There is no hierarchical structure for powerless groups to climb. In fact, in the case of women, power began at the top-when the denomination absorbed their missionary society in the 1920s (a process taking place in many Protestant bodies) women were compensated by proportional representation on national boards.

Harper: I want my work to emphasize three things: accuracy, fairness, and context. First, I want to be as accurate as possible in my assessment of a given source or situation. This is especially 
important when differing theological interpretations, strong personalities, and the like come into play. Second, I believe that if a story is worth telling, it should be told fairly. For instance, as a self-identifying conservative, I do not want to give short shrift to non-conservatives. Finally, each of us studies people and movements in specific contexts. I always want to keep that context in mind as I write or edit.

\section{Mullen: What kinds of denominational histories remain to be written?}

Prichard: I would like to see a history that treats the Methodist, Pentecostals, and Episcopalians as a group, noting historical connections and the persisting ecclesiological and theological similarities.

Harper: There are a number of works that I would like to see but I will try to be brief. First, I would like to see a critical biography of Francis Wayland, a Baptist educator and president of Brown University. Second, I would like to see a work that explores Baptists on the eve of the Civil War who did not want war.

Bendroth: I think there are all kinds of possibilities. Comparative studies, various groupings, and all that. But if we think of the denomination as a focus for inquiry, a petri dish of a sort, we can throw all kinds of different stimuli in and observe what happens.

It is an important-and increasingly relevant-line of inquiry, I would argue. How do people in local churches make decisions, manage differences, or choose leaders? Not in most cases according to their historic polity. They use the institutional model they are most familiar with, filling the void with the structures and, I would say, the values of corporate America. They watch the bottom line, hire and fire, create job descriptions, and evaluate progress according to deeply secular benchmarks. Needless to say, those don't have much to do with historic Protestantism, let alone the New Testament. They also don't work all that well. The old historic Protestant traditions are, in an odd way, more important than ever as we contemplate the moral frontiers of the twenty-first century.

Lincoln A. Mullen is an assistant professor in the Department of History and Art History at George Mason University. He is the author of The Chance of Salvation: A History of Conversion in America (Harvard University Press, 2017). 